\title{
Guest Editorial - CENA Executive Director
}

2008 has been an interesting year in many ways and one that seems to have simply disappeared. As we commence another new year, it is again timely to reflect on our last.

This time last year, the College of Emergency Nursing Australasia (CENA) welcomed a new Editor-in-Chief of the Australasian Emergency Nursing Journal (AENJ). The appointment of Ramon Shaban to that role has proven to be a wise and sound choice. Ramon has done us proud in the last twelve months, and has demonstrated his determination to build the AENJ, as promised. Ramon's vision for AENJ has unfolded over 2008, with more to come in the times ahead. His commitment to engaging and enabling the Editorial Board and members of the Editorial Management Team contributing to setting the future vision and direction has been invaluable. CENA wishes to especially thank Ramon Shaban, Marie Gerdtz and Belinda Donkin-Evers for all they have done during 2008 to promote the AENJ. We commend your efforts.

In Issue 11 (4) Ramon Shaban called for expressions of interest for Deputy Editors, Associate Editors, and the International Editorial Board, as elements of the unfolding AENJ Strategic Plan. This is an opportunity for many to become involved in the growth of AENJ. Applications close 31 January 2009. I encourage you to become a part of this. With more growth to come in 2009 and beyond, there is plenty of opportunity and goodwill to become involved and contribute to the growth of the AENJ.

It has been a good year for CENA, one in which CENA has continued to grow steadily. For this I thank our members who continue to support us and of course the CENA Board of Directors whose untiring efforts and commitment has allowed CENA to develop. Some of the highlights during 2008 include: the National conference; strengthening our links with the Australasian College for Emergency Medicine; the work on the joint position statement on Pain with ACEM, ACEN, CENA through the National Health and Medical Research Council/National Institute of Clinical Studies (NHMRC/NICS); CENA's involvement on the Cognate Committee on Organ and Tissue Donation; federal, state and territory representation of CENA within the Australian Resuscitation Council; and the Coalition of National Nursing Organisations, to name a few. Each of the branches is involved with their state health authorities in representing emergency nurses at local and state level. CENA is delighted that this involvement has grown in all states during 2008.

Our 3rd National Conference 'Networking: Crossing borders' held in Perth Western Australia 27-30 August 2008 was a success. 350 delegates joined us, which was wonderful. Thanks go to the Conference Organising Committee of Diane Langman, Shirilee Kerrison, Deidre Tame, Kerrianne Blondel, Deb Mortlock and Conference Design: Ben Thiessen and Natalie Sproule for all they did in bringing us a great conference.

On 12th September 2008, at the invitation of the Australasian College for Emergency Medicine (ACEM), CENA attended the ACEM Access Block Summit in Melbourne Victoria. Access block is the term that is familiar to us all, and describes the delay patients who need hospital admission experience in the Emergency Department (ED) when their inpatient bed is unavailable and occurs once that delay exceeds eight hours. Access block, resulting in ED overcrowding is regarded as the single biggest threat to the delivery of quality emergency care in Australia. The main cause of access block is a combination of an increase in emergency presentations and admissions alongside the need for more in-patient hospital beds. While no degree of access block is considered acceptable, research has revealed the functionality of an emergency department degrades once access block exceeds $10 \%$ of patients awaiting admission. ${ }^{1}$

The purpose of the summit was to find ways forward with access block issues in Australia or at least acknowledging the issue and disseminating it widely to politicians, health and hospital administrators, and academics with the combined support of Emergency Physicians and Emergency Nurses working together in this wider community to address the problem. Professor Drew Richardson says, More than $40 \%$ of patients receiving care in emergency departments (EDs) are waiting for ward beds, and $77 \%$ of those have been in the ED for more than eight hours. This snapshot of Australia's 90

\footnotetext{
1 'Australia's emergency department overcrowding needs urgent solutions' - Media Release 12 September 2008. http://www.acem.org.au/infocentre.
} 
emergency departments was taken on 1st September 2008, the fourth conducted by the Road Trauma and Emergency Medicine Unit of the Australian National University for the Australasian College for Emergency Medicine. ${ }^{2}$

CENA was represented by Executive Director Julie Finucane, Director and President CENA Victoria Sue Cowling, Director CENA Kathy Bailey, and CENA Victoria Branch Committee Member Suzanne Colby. The Federal Health Minister, Nicola Roxon MP, opened the Summit. In one of the media releases prior to the Summit titled, 'Experts seek solutions to access block for emergency patients' the then ACEM Vice-President Dr Sally McCarthy and Chair of the ACEM Access Block Committee said, "This is a great opportunity to bring the key people together - health care professionals, policy makers and politicians - to identify how we can work together to better tackle growing ED overcrowding and access block."'3 Some of Australia's eminent emergency medicine specialists, senior health system managers and academics joined together to address solutions to the growing problem of delayed access to emergency treatment. At the Summit, I argued on behalf of CENA that access block now affects most emergency departments in Australia, and that it was vital for the summit to address the issue and determine a way forward for their to be any real opportunity of quality and safety in emergency health care. As patients queue in corridors awaiting transfer to inpatient beds it is distressing for them, their relatives, and the staff who care for them. It is of particular concern to emergency nurses around the country as they juggle care for these inpatients while attending presenting emergency patients. Development of effective strategies to tackle these issues is a real priority for us. ${ }^{4}$ It is hoped that 2009 will see ACEM and CENA continuing to work together in our efforts to tackle this issue that cripples our ability to care for our emergency patients.

The work of the National Emergency Care Pain Management Initiative is progressing through the Implementation Phase where many sites in Australia have entered into a two year commitment working with NICS to monitor and develop local solutions to barriers to best practice pain management based on the national guidelines. It is great to be a part of this initiative and to work alongside NHMRC/NICS, ACEM, and ACEN, towards better care for our patients and improving the management of pain in our emergency departments. Prior to endorsement, the draft joint statement will be available for comment on the CENA website in January 2009. The Australian Organ and Tissue Donation and Transplantation Authority commences on 1st January 2009. CENA has been actively involved in the precursor to this: The Cognate Committee on Organ and Tissue Donation and Transplantation. In early 2009, ACEM and CENA will continue to work together with other specialists to finalise the Clinical Triggers for Emergency Departments related to Organ and Tissue Donation and Transplantation. ACCCN and ANZICS will work together to finalise Clinical Triggers for Intensive Care before handing this work over to the Authority.

Finally, in my editorial in 11 (1) one year ago, I invited those who had not published before to make a 2008 new-year resolution challenge in your professional life to publish. It has been a busy year for us all, and to those who have made time to commit to this important professional endeavour, I express my thanks. Publishing is essential to our professional growth and scholarship. If you did not get around to publishing in 2008 and you are keen to take up the challenge, make 2009 your year. There is so much help available to publish for the first time. The second time is so much easier then. Publishing is essential to promoting our image and our successes to our patients and the community we serve.

Finally, I take this opportunity to wish all our members and all our readers the very best during 2009 and hope for all that it will be a wonderful year personally and professionally for all of you, bringing you health and happiness, and all the best of everything. Take care of yourselves as I am sure it will be no less busy than the last one. Until next time stay safe and well.

Julie Finucane, OAM

Executive Director

College of Emergency Nursing Australasia,

Adjunct Senior Lecturer, School of Nursing and Midwifery, University of Queensland, Ipswich Campus,

Queensland, Australia

E-mail address: Julie_Finucane@health.qld.gov.au

\footnotetext{
2 'ED staff are spending one-third of their work caring for patients whose emergency treatment is over according to Professor Drew Richardson' - Media Release 24 November 2008. http://www.acem.org.au/infocentre.

3 'Experts seek solutions to 'access block' for emergency patients - Media Release 10 September 2008. http://www.acem.org.au/infocentre.

4 'Experts seek solutions to 'access block' for emergency patients - Media Release 10 September 2008. http://www.acem.org.au/infocentre.
} 